\author{
Tomasz Grabia \\ University of Lodz \\ e-mail: tomasz.grabia@uni.lodz.pl \\ ORCID: 0000-0001-7053-6618
}

\title{
WHY DO RICHER EU COUNTRIES HAVE A HIGHER PUBLIC DEBT RATIO THAN THEIR POORER COUNTERPARTS?
}

\section{DLACZEGO BOGATSZE KRAJE UE MAJĄ WYŻSZY WSKAŹNIK DEUGU PUBLICZNEGO NIŻ BIEDNIEJSZE?}

DOI: $10.15611 /$ pn.2019.12.03

JEL Classification: E31, E62, H6, O1

\begin{abstract}
Summary: This article aims to identify the factors differentiating public debt ratios among EU countries with different levels of development. The study period from 2000 to 2018 was adopted. The analysis was extended to the period of 1990-1996, for inflation only. In order to achieve the aim, a time-series analysis and correlation coefficients between selected categories were examined. Based on the above, the analysis indicates that differences in the public debt ratios in EU countries stemmed also from reasons that do not result from Keynesian and non-Keynesian effects, such as: (i) varying economic growth rates (according to the theory of real convergence); (ii) varying inflation rates; (iii) different conditions relating to the stabilization of debt ratios in the context of primary balance volumes.
\end{abstract}

Keywords: fiscal policy, public debt ratio, economic growth, inflation, primary balance.

Streszczenie: Celem artykułu jest identyfikacja czynników różnicujących wskaźniki długu publicznego w krajach UE o różnych poziomach rozwoju gospodarczego. Przyjęto okres badawczy od 2000 do 2018 r. W przypadku inflacji analiza została poszerzona także o lata 1990-1996. Aby osiągnąć cel, przeanalizowano szeregi czasowe oraz współczynniki korelacji między wybranymi kategoriami. Na podstawie przeprowadzonej analizy można stwierdzić, że różnice we wskaźnikach długu publicznego w krajach UE wynikały nie tylko $\mathrm{z}$ efektów keynesowskich i niekeynesowskich, ale również z takich czynników, jak: (i) zróżnicowane stopy wzrostu gospodarczego (zgodnie z teorią realnej konwergencji); (ii) zmienne stopy inflacji; (iii) różne warunki stabilizacji wskaźnika zadłużenia z punktu widzenia kształtowania się salda pierwotnego.

Słowa kluczowe: polityka fiskalna, wskaźnik długu publicznego, wzrost gospodarczy, inflacja, saldo pierwotne. 


\section{Introduction}

The problem of the consequences of an increase in public indebtedness has been a topic of discussion among both politicians and macroeconomists for years. Two conflicting views prevail, formulated, on the one hand, by representatives of trends associated with traditional Keynesianism, and, on the other hand, with the neoclassical school.

Among the former, the opinion predominates that fiscal expansion contributes to an aggregate demand' growth and, in conditions of spare capacities, also to increased aggregate production. Moreover, GDP growth can multiply due to the government spending multiplier which, in turn, directly depends on the marginal propensity to consume, the marginal propensity to save, the tax rate and the marginal propensity to import.

In contrast, advocates of the neoclassical approach point out that processes of growth in demand and national income may last only until bottlenecks appear, related to limited economic resources, which do not allow further production growth. In the long run, further stimulation of aggregate demand can cause producers to raise prices rather than the quantity of produced goods, thus the only result may be inflation.

The negative impact of government spending and growing debt on national income can also be related to the so-called non-Keynesian effects arising when changes in public sector demand are smaller than those caused in private sector demand (Rzońca, 2007, p. 21) as an increase in government expenditure does not remain neutral for other GDP components - especially investments and net exports.

A possible decline in investments may be linked to the so-called crowding out effect. A budget deficit increase means a decrease in national savings and the consequent rise in the equilibrium interest rate. The increase may also arise from the necessity to incur more loans, in which case the government must then propose a bond interest rate that is more favourable to buyers (Gale and Orszag, 2003). In line with that, other interest rates also increase, including those on deposits and loans in commercial banks, therefore investments financed with loans become limited.

Higher interest rates in the country also cause an inflow of foreign currency, followed by its depreciation with a simultaneous appreciation of the national currency. Such a situation may cause a fall in exports and an increase in imports. Then the so-called 'twin' deficit, i.e. a budget deficit accompanied by a trade balance deficit, can occur (Reynolds, 2001, p. 266), along with a decline in investments that could mean a fall in GDP.

It is also worth noting that higher interest rates reduce the value of the multiplier. They cause a decrease in the marginal propensity to consume and an increase in the marginal propensity for saving (Christiano, Eichenbaum, and Rebelo, 2009, pp. 1-5, 15-27; Rosati 2013, pp. 34-35). According to Eggertsson (2011, pp. 60, 79), in this case the multiplier may even be below 0.5 . 
The globalization process is also working towards lowering the multiplier. This means that a large part of the profits (interest) on bonds goes to foreign investors (non-residents), without contributing to the increase in domestic consumption (Cassimon, Moreno-Dodson, and Wodon, 2008, p. 41). In addition, globalization increases the marginal propensity to import.

Dilemmas related to conflicting views (about the Keynesian and non-Keynesian effects of fiscal expansion) have been given a lot of space in literature. The positive impact of fiscal expansion on GDP was demonstrated, among others, by Fatás and Mihov (2001), Favero (2002), Perotti (2003), Giordano, Momigliano, Neri and Perotti (2007), and Afonso and Sousa (2011). In turn, the negative impact of expansionary fiscal policy on GDP resulted from research conducted by Ramey and Shapiro (1998), Mountford and Uhlig (2005), Castro and Cos (2008), and Reinhart and Rogoff (2010). In such a situation, if non-Keynesian effects are stronger, fiscal consolidation may prove beneficial for GDP (Giudice, Turrini, and Veld, 2003).

In this article the analysis is focused on issues outside the mainstream dispute about the relationship between GDP and public debt, which so far have been given less space in literature. The purpose of the article is to identify other factors that do not directly result from Keynesian and non-Keynesian effects that differentiate the public debt ratio between EU countries with different levels of economic development.

The study consists of an introduction, two main parts and a summary. The first part presents an illustration of GDP per capita according to the purchasing power standard and the public debt-to-GDP ratio. The next part discusses the reasons for public debt in the developed countries exceeding that of the less developed ones. In this context, attention is paid to the real convergence process, the inflation rate, and the conditions for debt ratio stabilization from the point of view of the primary balance. Statistical data comes from the Eurostat database and the Statistical Yearbooks of the Republic of Poland. The 2000-2018 research period or, due to unavailability of data, the 2004-2018 research period was adopted. For inflation, the analysis was extended to the period 1990-1996. The article ends with a summary containing conclusions drawn from previous observations.

\section{Economic development and public debt in the EU-28}

\subsection{Economic development}

In international comparisons, GDP per capita is the most important measure of economic development, according to purchasing power standard. Table 1 presents the values of the measure in all Member States (EU-28) in the 2004-2018 period (due to unavailability of data in the Eurostat database for 2000-2003), assuming the average for the entire Union (EU-28) as a base equal to 100. Countries were ordered from the highest to the lowest value of the analysed variable in 2018 (the names of the old EU countries (EU-15) were put in bold, also in the other tables). 
Table 1. GDP per capita according to PPS in the EU-28 in 2004-2018

\begin{tabular}{|l|c|c|c|c||l|c|c|c|c|}
\hline \multicolumn{1}{|c|}{ Country } & 2004 & 2008 & 2013 & 2018 & Country & 2004 & 2008 & 2013 & 2018 \\
\hline Luxembourg & $\mathbf{2 4 6}$ & $\mathbf{2 6 2}$ & $\mathbf{2 6 1}$ & $\mathbf{2 5 4}$ & Czechia & 79 & 84 & 84 & 90 \\
\hline Ireland & $\mathbf{1 4 3}$ & $\mathbf{1 3 4}$ & $\mathbf{1 3 2}$ & $\mathbf{1 8 7}$ & Cyprus & 97 & 105 & 84 & 87 \\
\hline Netherlands & $\mathbf{1 3 3}$ & $\mathbf{1 4 0}$ & $\mathbf{1 3 5}$ & $\mathbf{1 2 9}$ & Slovenia & 86 & 90 & 82 & 87 \\
\hline Austria & $\mathbf{1 2 8}$ & $\mathbf{1 2 5}$ & $\mathbf{1 3 1}$ & $\mathbf{1 2 7}$ & Estonia & 55 & 68 & 75 & 81 \\
\hline Denmark & $\mathbf{1 2 5}$ & $\mathbf{1 2 5}$ & $\mathbf{1 2 8}$ & $\mathbf{1 2 6}$ & Lithuania & 50 & 63 & 73 & 81 \\
\hline Germany & $\mathbf{1 1 6}$ & $\mathbf{1 1 7}$ & $\mathbf{1 2 4}$ & $\mathbf{1 2 3}$ & Slovakia & 57 & 71 & 76 & 78 \\
\hline Sweden & $\mathbf{1 2 9}$ & $\mathbf{1 2 7}$ & $\mathbf{1 2 5}$ & $\mathbf{1 2 1}$ & Portugal & $\mathbf{7 7}$ & $\mathbf{8 1}$ & $\mathbf{7 6}$ & $\mathbf{7 6}$ \\
\hline Belgium & $\mathbf{1 2 1}$ & $\mathbf{1 1 5}$ & $\mathbf{1 2 0}$ & $\mathbf{1 1 5}$ & Poland & 49 & 55 & 67 & 71 \\
\hline Finland & $\mathbf{1 1 7}$ & $\mathbf{1 2 1}$ & $\mathbf{1 1 3}$ & $\mathbf{1 1 0}$ & Hungary & 62 & 63 & 67 & 70 \\
\hline United Kingdom & $\mathbf{1 2 5}$ & $\mathbf{1 1 0}$ & $\mathbf{1 0 8}$ & $\mathbf{1 0 4}$ & Latvia & 48 & 59 & 62 & 70 \\
\hline France & $\mathbf{1 1 0}$ & $\mathbf{1 0 6}$ & $\mathbf{1 0 8}$ & $\mathbf{1 0 4}$ & Greece & $\mathbf{9 5}$ & $\mathbf{9 3}$ & $\mathbf{7 2}$ & $\mathbf{6 8}$ \\
\hline Malta & 81 & 79 & 86 & 98 & Romania & 34 & 51 & 54 & 64 \\
\hline Italy & $\mathbf{1 0 8}$ & $\mathbf{1 0 6}$ & $\mathbf{9 8}$ & $\mathbf{9 5}$ & Croatia & 57 & 63 & 60 & 63 \\
\hline Spain & $\mathbf{1 0 0}$ & $\mathbf{1 0 1}$ & $\mathbf{8 9}$ & $\mathbf{9 1}$ & Bulgaria & 34 & 43 & 45 & 50 \\
\hline
\end{tabular}

Source: (The Eurostat database, n.d.).

Based on the table, it can be concluded that despite the process of real convergence, the division into the 'old' and 'new' Union is still clearly visible. Differences in the development levels remain significant which may be confirmed by the fact that the old EU countries (EU-15) ranked first to eleventh at the end of the analysed period. Among those, only Greece and Portugal were not in the group of twenty most developed countries.

\subsection{Public debt ratio}

The public debt ratio is usually given in relation to GDP rather than in absolute terms. The Maastricht Treaty set the reference value at $60 \%$ of GDP. Table 2 presents the public debt ratios in the analysed countries in selected years from 2000 to 2018.

The first conclusion that can be drawn from Table 2 is the apparent tendency for the ratio of public debt to GDP to increase, particularly in the years 2009-2012, and to decrease in 2013-2018. The former trend can be explained by the deepening economic crisis in 2009 during which budget revenues were lower, while expenditures on payment transfers rose. The latter tendency was associated with improved economic conditions.

Considering the entire European Union, at the end of the analysed period the public debt ratio lower than $30 \%$ was only found in three countries: Estonia, Luxembourg and Bulgaria. In addition, the $60 \%$ threshold, which was the Maastricht criterion, was not exceeded by the following eleven countries: Czechia, Denmark, 
Table 2. Public debt ratio (in \% of GDP) in the EU-28 in 2000-2018

\begin{tabular}{|l|l|l|l|l|l||l|l|l|l|l|l|}
\hline \multicolumn{1}{|c|}{ Country } & 2000 & 2004 & 2008 & 2013 & 2018 & Country & 2000 & 2004 & 2008 & 2013 & 2018 \\
\hline Estonia & 5.1 & 5.1 & 4.5 & 10.2 & 8.4 & Germany & $\mathbf{5 8 . 9}$ & $\mathbf{6 4 . 8}$ & $\mathbf{6 5 . 2}$ & $\mathbf{7 8 . 2}$ & $\mathbf{6 0 . 9}$ \\
\hline Luxembourg & $\mathbf{7 . 2}$ & $\mathbf{7 . 3}$ & $\mathbf{1 4 . 9}$ & $\mathbf{2 3 . 7}$ & $\mathbf{2 1 . 4}$ & Ireland & $\mathbf{3 6 . 1}$ & $\mathbf{2 8 . 2}$ & $\mathbf{4 2 . 4}$ & $\mathbf{1 1 9 . 7}$ & $\mathbf{6 4 . 8}$ \\
\hline Bulgaria & 71.2 & 36 & 13 & 17.1 & 22.6 & Slovenia & 25.9 & 26.8 & 21.8 & 70.4 & 70.1 \\
\hline Czechia & 17 & 28.5 & 28.3 & 44.9 & 32.7 & Hungary & 55.3 & 58.7 & 71.6 & 77.2 & 70.8 \\
\hline Denmark & $\mathbf{5 2 . 4}$ & $\mathbf{4 4 . 2}$ & $\mathbf{3 3 . 3}$ & $\mathbf{4 4}$ & $\mathbf{3 4 . 1}$ & Austria & $\mathbf{6 6 . 1}$ & $\mathbf{6 5 . 2}$ & $\mathbf{6 8 . 7}$ & $\mathbf{8 1 . 3}$ & $\mathbf{7 3 . 8}$ \\
\hline Lithuania & 23.5 & 18.7 & 14.6 & 38.8 & 34.2 & Croatia & 35.5 & 40.3 & 39 & 80.4 & 74.6 \\
\hline Romania & 22.5 & 18.9 & 12.4 & 37.6 & 35 & United & $\mathbf{3 7}$ & $\mathbf{3 8 . 6}$ & $\mathbf{4 9 . 7}$ & $\mathbf{8 5 . 2}$ & $\mathbf{8 6 . 8}$ \\
& 12.1 & 14 & 18.2 & 39.4 & 35.9 & Spain & $\mathbf{5 8}$ & $\mathbf{4 5 . 3}$ & $\mathbf{3 9 . 5}$ & $\mathbf{9 5 . 5}$ & $\mathbf{9 7 . 1}$ \\
\hline Latvia & $\mathbf{5 0 . 7}$ & $\mathbf{4 8 . 9}$ & $\mathbf{3 7 . 7}$ & $\mathbf{4 0 . 7}$ & $\mathbf{3 8 . 8}$ & France & $\mathbf{5 8 . 9}$ & $\mathbf{6 5 . 9}$ & $\mathbf{6 8 . 8}$ & $\mathbf{9 3 . 4}$ & $\mathbf{9 8 . 4}$ \\
\hline Sweden & 60.9 & 71.9 & 62.6 & 68.4 & 46 & Belgium & $\mathbf{1 0 8 . 8}$ & $\mathbf{9 6 . 5}$ & $\mathbf{9 2 . 5}$ & $\mathbf{1 0 5 . 5}$ & $\mathbf{1 0 2}$ \\
\hline Malta & 36.5 & 45 & 46.3 & 55.7 & 48.9 & Cyprus & 55.7 & 64.8 & 45.6 & 103.1 & 102.5 \\
\hline Poland & 49.6 & 40.6 & 28.5 & 54.7 & 48.9 & Portugal & $\mathbf{5 0 . 3}$ & $\mathbf{6 2}$ & $\mathbf{7 1 . 7}$ & $\mathbf{1 2 9}$ & $\mathbf{1 2 1 . 5}$ \\
\hline Slovakia & $\mathbf{5 2 . 1}$ & $\mathbf{5 0 . 3}$ & $\mathbf{5 4 . 7}$ & $\mathbf{6 7 . 7}$ & $\mathbf{5 2 . 4}$ & Italy & $\mathbf{1 0 5 . 1}$ & $\mathbf{1 0 0 . 1}$ & $\mathbf{1 0 2 . 4}$ & $\mathbf{1 2 9}$ & $\mathbf{1 3 2 . 2}$ \\
\hline Netherlands & $\mathbf{4 2 . 5}$ & $\mathbf{4 2 . 7}$ & $\mathbf{3 2 . 7}$ & $\mathbf{5 6 . 5}$ & $\mathbf{5 8 . 9}$ & Greece & $\mathbf{1 0 4 . 9}$ & $\mathbf{1 0 2 . 9}$ & $\mathbf{1 0 9 . 4}$ & $\mathbf{1 7 7 . 4}$ & $\mathbf{1 8 1 . 1}$ \\
\hline Finland & & & & & & & & & & &
\end{tabular}

Source: (The Eurostat database, n.d.).

Lithuania, Romania, Latvia, Sweden, Malta, Poland, Slovakia, the Netherlands and Finland. It should be noted that out of fourteen countries that did not exceed the reference value, only five (Luxembourg, the Netherlands and three Scandinavian countries) joined the EU in the 20th century, while as many as nine are new members of the EU.

In the other fourteen countries of the EU-28, public debt at the end of 2018 was higher than that recommended in the Maastricht Treaty. The group included four countries which became members of the EU in this century (Slovenia, Hungary, Croatia and Cyprus) and ten EU-15 countries (Germany, Ireland, Austria, the United Kingdom, Spain, France, Belgium, Portugal, Italy and Greece). Of all the countries that exceeded the reference value, the worst state of public finances (over $90 \%$ of the debt ratio) was found in Greece, Portugal, Italy, Ireland, Belgium, Cyprus, France and Spain. All the countries, except for Cyprus, are representatives of the 'old', on average still more developed, EU.

The differences would probably be even greater if many EU-15 countries did not have to reduce their debt at the end of the 20th century. That was connected with the need to fulfil the Maastricht fiscal criteria before joining the euro area (Bukowski, 2011, p. 146). This concerned, among others, Belgium, Denmark, Ireland, Spain, Italy, the Netherlands and Sweden. However, the phenomenon should not be overestimated due to the fact that after obtaining membership the budget discipline in those countries usually deteriorated once again. In addition, since 2007, the new 
EU countries (Slovenia, Cyprus, Malta, Slovakia, Estonia, Latvia and Lithuania) have also joined the euro area. Among them, the need to reduce debt before the adoption of the single European currency occurred only in the case of Slovakia.

Table 3. Correlation coefficient between public debt ratio and GDP per capita according to PPS in the EU-28 in 2004-2018

\begin{tabular}{|l|r|r|r|r|}
\hline \multicolumn{1}{|c|}{ Year } & 2004 & 2008 & 2013 & 2018 \\
\hline EU-28 & 0.10 & 0.08 & -0.06 & -0.17 \\
\hline EU-26 (excluding Luxembourg and Greece) & 0.46 & 0.44 & 0.35 & 0.12 \\
\hline
\end{tabular}

Source: own calculations based on Tables 1 and 2 .

The above analysis may indicate the validity of the question asked in the title of this paper. However, it is also worth presenting the correlation coefficients between the public debt ratio and GDP per capita according to PPS. The ratios are shown in Table 3. This does not unambiguously indicate that countries with higher GDP per capita had higher public debt ratios since the correlation coefficients between the variables were very low (below 0.2 ) in all the four examined years and even negative in 2013 and 2018.

The last row of Table 3 also presents the correlation coefficients, excluding Luxembourg and Greece as the countries can be deemed unusual considering the question posed in the title. Luxembourg has the highest level of economic development and one of the lowest public debt indicators in Europe, and Greece is currently one of the weakest EU countries in terms of GDP per capita with the highest debt by far. After eliminating atypical observations, the correlation coefficients were positive and definitely higher in each case. It is worth noting, however, that the one-way relationship between economic development (GDP per capita according to PPS) and the public debt ratio has distinctly weakened recently (correlation coefficient 0.12 in 2018 versus $0.35-0.46$ in 2004-2013).

The analysis shows that as a rule, except for extreme cases, richer (more developed) countries are more indebted than poorer (less developed) ones. However, this does not decide the validity of the thesis that the Keynesian effects of expansionary fiscal policy prevailed in Europe in 2000-2018. Firstly, the correlation coefficients were not high, especially at the end of the considered period. Secondly, other conclusions could be drawn if the relationship between public debt and real GDP growth rate (instead of GDP per capita) was examined, which is highlighted later in this article. Finally, the reasons for the positive relationship between public debt and economic development may also be related to other factors. The most important of them include the real convergence process, diverse inflation rates, as well as conditions of the primary balance required for debt ratio stabilization. The issues will be the subject of analysis later in the article. 


\section{Determinants of the diversified indebtedness of the EU-28}

\subsection{Real convergence}

Table 4 presents the annual real GDP growth rates in the EU countries in the period 2000-2018 and in three subperiods: 2000-2006, 2007-2012 and 2013-2018. Taking into account the whole studied period, Ireland, Lithuania, Romania, Estonia and Latvia were the fastest developing countries (an average economic growth of 4\%$-5 \%)$, followed by Slovakia, Poland, Bulgaria, Malta and Luxembourg (3\%-4\%). Among the ten countries, only Ireland exceeded the public debt reference value specified in the Maastricht Treaty at the end of the study period.

In turn, the slowest developing EU countries in the 2000-2018 period, i.e. Portugal and Greece (below 1\% yearly on average), were characterised by the highest public debt ratios. Thus, while analysing economic growth rates rather than GDP per capita, different conclusions may be drawn on the Keynesian effects of fiscal expansion as the countries with lower public debt ratios typically developed faster than those with higher public debt ratios. This is also indicated by the relatively high $(-0.68)$ correlation coefficient between the average rate of economic growth in the analysed period and public debt in 2018.

On the other hand, it is worth emphasising that to a large extent this arose from the real convergence theory. Among the ten fastest developing EU countries in the

Table 4. Average real GDP growth rate in the EU-28 in 2000-2018

\begin{tabular}{|l|c|c|c|c||l|c|c|c|c|}
\hline \multicolumn{1}{|c|}{ Country } & $\begin{array}{c}2000- \\
-2018\end{array}$ & $\begin{array}{c}2000- \\
-2006\end{array}$ & $\begin{array}{c}2007- \\
-2012\end{array}$ & $\begin{array}{c}2013- \\
-2018\end{array}$ & Country & $\begin{array}{c}2000- \\
-2018\end{array}$ & $\begin{array}{c}2000- \\
-2006\end{array}$ & $\begin{array}{c}2007- \\
-2012\end{array}$ & $\begin{array}{c}2013- \\
-2018\end{array}$ \\
\hline Ireland & $\mathbf{5 . 0}$ & $\mathbf{5 . 9}$ & $\mathbf{- 0 . 3}$ & $\mathbf{9 . 2}$ & Cyprus & 2.0 & 3.6 & 0.9 & 1.4 \\
\hline Lithuania & 4.2 & 7.2 & 1.7 & 3.2 & Croatia & 2.0 & 4.4 & -0.7 & 1.8 \\
\hline Romania & 4.0 & 5.6 & 1.9 & 4.5 & United Kingdom & $\mathbf{1 . 9}$ & $\mathbf{3 . 1}$ & $\mathbf{0 . 5}$ & $\mathbf{2 . 0}$ \\
\hline Estonia & 4.0 & 8.0 & 0.3 & 3.2 & Spain & $\mathbf{1 . 8}$ & $\mathbf{3 . 6}$ & $-\mathbf{0 . 4}$ & $\mathbf{2 . 0}$ \\
\hline Latvia & 4.0 & 8.3 & -0.2 & 3.1 & Austria & $\mathbf{1 . 7}$ & $\mathbf{2 . 3}$ & $\mathbf{1 . 1}$ & $\mathbf{1 . 5}$ \\
\hline Slovakia & 3.9 & 4.9 & 3.4 & 3.2 & Finland & $\mathbf{1 . 6}$ & $\mathbf{3 . 3}$ & $\mathbf{0 . 3}$ & $\mathbf{1 . 1}$ \\
\hline Poland & 3.8 & 3.7 & 4.0 & 3.6 & Netherlands & $\mathbf{1 . 5}$ & $\mathbf{2 . 0}$ & $\mathbf{0 . 7}$ & $\mathbf{1 . 8}$ \\
\hline Bulgaria & 3.6 & 5.7 & 2.2 & 2.8 & Belgium & $\mathbf{1 . 5}$ & $\mathbf{2 . 1}$ & $\mathbf{1 . 1}$ & $\mathbf{1 . 3}$ \\
\hline Malta & 3.6 & 1.5 & 2.1 & 7.2 & Italy & $\mathbf{1 . 5}$ & $\mathbf{4 . 4}$ & $\mathbf{- 0 . 9}$ & $\mathbf{0 . 5}$ \\
\hline Luxembourg & $\mathbf{3 . 1}$ & $\mathbf{4 . 5}$ & $\mathbf{1 . 6}$ & $\mathbf{3 . 1}$ & Germany & $\mathbf{1 . 4}$ & $\mathbf{1 . 4}$ & $\mathbf{1 . 2}$ & $\mathbf{1 . 7}$ \\
\hline Czechia & 2.9 & 4.5 & 1.1 & 2.9 & France & $\mathbf{1 . 4}$ & $\mathbf{2 . 0}$ & $\mathbf{0 . 7}$ & $\mathbf{1 . 3}$ \\
\hline Slovenia & 2.4 & 4.0 & 0.3 & 2.8 & Denmark & $\mathbf{1 . 2}$ & $\mathbf{1 . 9}$ & $\mathbf{- 0 . 2}$ & $\mathbf{1 . 8}$ \\
\hline Hungary & 2.4 & 4.1 & -0.8 & 3.5 & Portugal & $\mathbf{0 . 7}$ & $\mathbf{1 . 4}$ & $\mathbf{- 0 . 7}$ & $\mathbf{1 . 4}$ \\
\hline Sweden & $\mathbf{2 . 3}$ & $\mathbf{3 . 2}$ & $\mathbf{1 . 0}$ & $\mathbf{2 . 6}$ & Greece & $\mathbf{0 . 4}$ & $\mathbf{4 . 3}$ & $\mathbf{- 3 . 9}$ & $\mathbf{0 . 1}$ \\
\hline
\end{tabular}

Source: own calculations based on (The Eurostat database, n.d.). 
study period, as many as seven (all except Ireland, Luxembourg and Malta) were among the 11 least developed countries in 2018 (GDP per capita according to PPS below $81 \%$ of the average for the EU-28).

It should be emphasized that there is nothing extraordinary in the fact that less developed countries are characterized by higher economic growth. In this context it is worth noting that GDP is a stream, not a resource. Therefore, for example, the construction of roads, motorways, stadiums, halls and stations annually increased GDP in many new EU countries. In the EU-15, such investments were not made as they were unnecessary - the infrastructure was already developed there. The EU funds that went to poorer countries were also conducive to the real convergence process.

Nonetheless, it should be emphasized that the real convergence process is slow in the EU, which is evidenced by the very low $(-0.02)$ correlation coefficient between the average rate of economic growth in the study period and GDP per capita according to PPS in 2018. However, if the two most untypical observations are eliminated (Luxembourg and Greece), the ratio increases up to -0.18 .

In terms of the problem discussed in the article, it should be emphasized that the faster growing real GDP in the poorer (less developed) EU countries means that their debt ratios are growing, ceteris paribus, at a slower pace (or, recently, falls faster) than in the richer (more developed) ones. This results directly from the construction of the indicator, which is calculated as the relation of debt to GDP. In addition, an indirect impact may also be considered arising from the fact that dependencies between economic growth and tax revenues are usually positive (due to higher production and higher employment in good times), while they are negative between economic growth and budget expenditures (due to lower social spending during recovery and prosperity). In countries where the pace of economic growth is slower, cyclical deficits are higher too, which causes the debt ratio to rise (Grabia, 2015, p. 48).

\subsection{Diversified inflation}

While examining the relationship between public debt and inflation, it is generally assumed in the literature that the former is the exogenous variable. As a rule, a rise in public debt is shown to increase inflation (see, among others, Kwon, McFarlane, and Robinson (2006); Lopes da Veiga, Ferreira-Lopes, and Sequeira (2014); Mishkin and Savastano (2000); Nguyen (2015), and Romero and Marin (2017).

However, it can be alternatively assumed that the public debt ratio is the endogenous variable whereas inflation is the exogenous one. It should be emphasized that inflation may be beneficial to the state. One of the main reasons is that there is a channel of income redistribution caused by inflation - in fact, incomes move from lenders to borrowers. It should be kept in mind that currently the largest borrowers are governments which issue treasury bonds in order to finance their deficits. Therefore, inflation may be beneficial to the state due to the fact that it reduces the real value of debt (Burda and Wyplosz, 2000, p. 495). 
Table 5 presents average (yearly) inflation rates (HICP) in the EU-28 in the period 2000-2018 and three subperiods: 2000-2006, 2007-2012 and 2013-2018. Table 5 shows that, as a rule, higher inflation was observed in the countries that joined the EU in this century. However, it is worth noting that, apart from Romania and, to a lesser extent, Hungary, Bulgaria, Latvia, Estonia, Slovakia and Slovenia, differences in their inflation rates were relatively insignificant in the EU-28 (apart from the above-mentioned countries, the average inflation rate was the lowest in Germany and Sweden $-1.5 \%$ - and the highest in Poland - 2.6\%). Nevertheless, the negative $(-0.32)$ correlation coefficient between the average inflation rate in the study period and public debt in 2018 may indicate a certain inverse relationship between the analysed variables.

Table 5. Average (annual) inflation rate (HICP) in the EU-28 in 2000-2018

\begin{tabular}{|l|c|c|c|c||l|c|c|c|c|}
\hline \multicolumn{1}{|c|}{ Country } & $2000-$ & $2000-$ & $2007-$ & $2013-$ & Country & $\begin{array}{c}2000- \\
-2018\end{array}$ & $\begin{array}{c}2000- \\
-2006\end{array}$ & $\begin{array}{c}2007- \\
-2012\end{array}$ & $\begin{array}{c}2013- \\
-2018\end{array}$ \\
\hline Germany & $\mathbf{1 . 5}$ & $\mathbf{1 . 6}$ & $\mathbf{1 . 9}$ & $\mathbf{1 . 1}$ & Malta & 2.1 & 2.5 & 2.5 & 1.2 \\
\hline Sweden & $\mathbf{1 . 5}$ & $\mathbf{1 . 6}$ & $\mathbf{1 . 9}$ & $\mathbf{1 . 2}$ & United Kingdom & $\mathbf{2 . 1}$ & $\mathbf{2 . 3}$ & $\mathbf{2 . 8}$ & $\mathbf{1 . 2}$ \\
\hline Denmark & $\mathbf{1 . 6}$ & $\mathbf{2 . 0}$ & $\mathbf{1 . 9}$ & $\mathbf{0 . 9}$ & Spain & $\mathbf{2 . 2}$ & $\mathbf{3 . 3}$ & $\mathbf{2 . 4}$ & $\mathbf{0 . 7}$ \\
\hline France & $\mathbf{1 . 6}$ & $\mathbf{2 . 0}$ & $\mathbf{2 . 3}$ & $\mathbf{0 . 5}$ & Croatia & 2.3 & 3.0 & 2.7 & 1.1 \\
\hline Finland & $\mathbf{1 . 7}$ & $\mathbf{1 . 6}$ & $\mathbf{2 . 6}$ & $\mathbf{0 . 9}$ & Luxembourg & $\mathbf{2 . 3}$ & $\mathbf{3 . 2}$ & $\mathbf{2 . 9}$ & $\mathbf{0 . 8}$ \\
\hline Ireland & $\mathbf{1 . 7}$ & $\mathbf{3 . 6}$ & $\mathbf{1 . 0}$ & $\mathbf{0 . 3}$ & Lithuania & 2.5 & 1.4 & 4.9 & 1.3 \\
\hline Cyprus & 1.8 & 2.8 & 2.7 & -0.2 & Poland & 2.6 & 3.6 & 3.5 & 0.5 \\
\hline Italy & $\mathbf{1 . 8}$ & $\mathbf{2 . 4}$ & $\mathbf{2 . 4}$ & $\mathbf{0 . 7}$ & Slovenia & 3.2 & 5.6 & 2.9 & 0.8 \\
\hline Netherlands & $\mathbf{1 . 8}$ & $\mathbf{2 . 6}$ & $\mathbf{1 . 8}$ & $\mathbf{1 . 0}$ & Slovakia & 3.5 & 6.6 & 2.5 & 0.8 \\
\hline Austria & $\mathbf{1 . 9}$ & $\mathbf{1 . 9}$ & $\mathbf{2 . 3}$ & $\mathbf{1 . 6}$ & Estonia & 3.5 & 3.7 & 4.9 & 2.0 \\
\hline Belgium & $\mathbf{2 . 0}$ & $\mathbf{3 . 1}$ & $\mathbf{2 . 0}$ & $\mathbf{0 . 7}$ & Latvia & 3.7 & 4.2 & 5.7 & 1.1 \\
\hline Portugal & $\mathbf{2 . 0}$ & $\mathbf{2 . 1}$ & $\mathbf{2 . 4}$ & $\mathbf{1 . 4}$ & Bulgaria & 4.0 & 6.5 & 5.2 & 0.0 \\
\hline Czechia & 2.1 & 1.5 & 3.1 & 1.7 & Hungary & 4.4 & 6.2 & 5.4 & 1.3 \\
\hline Greece & $\mathbf{2 . 1}$ & $\mathbf{3 . 4}$ & $\mathbf{2 . 9}$ & $\mathbf{- 0 . 3}$ & Romania & 9.9 & 20.8 & 5.6 & 1.4 \\
\hline
\end{tabular}

Source: own calculations based on (The Eurostat database, n.d.).

It is worth noting, however, that particularly large differences in inflation in the analysed countries occurred not in the studied period, but earlier, when the transformation process began in countries that joined the EU in the 21st century. It was characterized by freeing up prices that previously, due to the mandatory command and distribution system, were entirely controlled by the state.

These differences were particularly strong in the period 1990-1996. They are presented in Table 6 , which contains the six-year period price indexes ${ }^{1}$. The analysis

${ }^{1}$ Due to the availability of data, only selected countries were analysed. Among the EU-15 countries, Ireland, Luxembourg and Portugal were not included in the analysis. Among the countries that joined the EU in the 21st century, the analysis did not include Bulgaria, Croatia, Cyprus and Malta. 
of the data presented in the table shows the scale of disproportions in inflation between the EU-15 and the new EU members. In the former, the overall price level increased the most in Greece (it more than doubled) from the end of 1990 to the end of 1996. In the other countries of the 'old' Union, the increase did not exceed 33\%.

Table 6. Six-year consumer price index in the selected EU-28 countries in $1996(1990=100)$

\begin{tabular}{|c|c|c|c|}
\hline Country & $\begin{array}{l}\text { Consumer Price } \\
\text { Index }\end{array}$ & Country & $\begin{array}{l}\text { Consumer Price } \\
\text { Index }\end{array}$ \\
\hline Denmark & 113 & Greece & 207 \\
\hline Finland & 113 & Estonia & $234^{\mathrm{a}}$ \\
\hline France & 114 & Czechia & 275 \\
\hline Belgium & 115 & Slovakia & 288 \\
\hline Netherlands & 117 & Hungary & 383 \\
\hline Germany & 117 & Latvia & $417^{\mathrm{b}}$ \\
\hline Austria & 119 & Slovenia & $616^{\mathrm{c}}$ \\
\hline United Kingdom & 121 & Poland & 667 \\
\hline Sweden & 123 & Lithuania & $1526^{\mathrm{b}}$ \\
\hline Spain & 133 & Romania & $4805^{\mathrm{c}}$ \\
\hline Italy & 133 & & \\
\hline
\end{tabular}

${ }^{\mathrm{a}} 1993=100 ;{ }^{\mathrm{b}} 1992=100 ;{ }^{\mathrm{c}} 1991=100$.

Source: (Rocznik Statystyczny RP, 1997, p. 600).

A completely different situation occurred in countries undergoing transformation, where the prices increased several or even several dozen times faster ${ }^{2}$. Galloping inflation, and in many cases even hyperinflation, in the new EU countries caused a very significant reduction in the real public debt level, as a result of which those countries were characterized by a significantly lower public debt ratio than the EU-15 countries in the 1997-2004 period. A different starting point also influenced the diversity of the later state of public finances in the EU-28. Even significant increase in public debt ratios in the new EU members did not cause the Maastricht reference value to be exceeded at the end of the analysed period.

\subsection{Diversified conditions for stabilizing debt ratio}

The structure of the public debt ratio indicates that its stabilization would require a surplus of the primary budget proportional to the difference between the real interest rate and the real GDP growth rate. If the latter was greater than the real interest rate, the public debt ratio would be able to stabilize even at a certain level of the primary deficit (Burda and Wyplosz, 2000, p. 494).

${ }^{2}$ Due to the availability of data, the indexes presented in Table 6 for Romania, Slovenia, Lithuania, Latvia and Estonia refer to a period shorter than six years. 
On the basis of economic growth rates, inflation rates and interest rates, it is possible to determine conditions for stabilizing the public debt ratio in individual countries. The average values of the variables for the EU-28 excluding Estonia (due to unavailability of interest rate data) for 2001-2018 (the year 2000 was excluded from the analysis as interest rate data was unavailable for new EU members) are presented in Table 7. In addition, the tables also contain calculations of the differences

Table 7. Average primary balance values ensuring public debt ratio stabilization in the EU-28 in 2000-2018

\begin{tabular}{|c|c|c|c|c|c|}
\hline Country & $\begin{array}{c}\text { Average } \\
\text { real GDP } \\
\text { growth rate } \\
(\mathrm{g})\end{array}$ & $\begin{array}{c}\text { Average } \\
\text { nominal } \\
\text { interest rate } \\
(\mathrm{r}) \\
\end{array}$ & $\begin{array}{c}\text { Average } \\
\text { inflation rate } \\
\text { (i) }\end{array}$ & $g-(r-i)$ & $\begin{array}{l}\text { Average primary } \\
\text { balance values en } \\
\text { suring public debt } \\
\text { ratio stabilization }\end{array}$ \\
\hline Romania & 4.1 & 6.1 & 7.9 & 5.9 & -5.9 \\
\hline Slovakia & 4 & 3.8 & 3 & 3.2 & -3.2 \\
\hline Bulgaria & 3.5 & 4.2 & 3.7 & 3 & -3.0 \\
\hline Latvia & 3.9 & 4.7 & 3.8 & 3 & -3.0 \\
\hline Luxembourg & 2.8 & 2.6 & 2.2 & 2.4 & -2.4 \\
\hline Ireland & 4.7 & 3.9 & 1.5 & 2.3 & -2.3 \\
\hline Lithuania & 4.2 & 4.5 & 2.5 & 2.2 & -2.2 \\
\hline Malta & 3.6 & 3.8 & 2 & 1.8 & -1.8 \\
\hline Czechia & 2.9 & 3.3 & 2 & 1.6 & -1.6 \\
\hline Slovenia & 2.3 & 4.1 & 2.9 & 1.1 & -1.1 \\
\hline Sweden & 2.2 & 2.9 & 1.5 & 0.8 & -0.8 \\
\hline Austria & 1.6 & 2.9 & 1.9 & 0.6 & -0.6 \\
\hline Poland & 3.7 & 5.3 & 2.2 & 0.6 & -0.6 \\
\hline United Kingdom & 1.8 & 3.3 & 2.1 & 0.6 & -0.6 \\
\hline Netherlands & 1.4 & 2.8 & 1.8 & 0.4 & -0.4 \\
\hline Belgium & 1.4 & 3.1 & 2 & 0.3 & -0.3 \\
\hline Germany & 1.3 & 2.6 & 1.6 & 0.3 & -0.3 \\
\hline Finland & 1.4 & 2.8 & 1.6 & 0.2 & -0.2 \\
\hline Hungary & 2.3 & 6.3 & 4.1 & 0.1 & -0.1 \\
\hline Spain & 1.7 & 3.7 & 2.1 & 0.1 & -0.1 \\
\hline Denmark & 1.1 & 2.8 & 1.5 & -0.2 & 0.2 \\
\hline France & 1.2 & 3 & 1.6 & -0.2 & 0.2 \\
\hline Croatia & 1.9 & 4.8 & 2.2 & -0.7 & 0.7 \\
\hline Italy & 1.3 & 3.9 & 1.8 & -0.8 & 0.8 \\
\hline Cyprus & 1.9 & 5 & 1.7 & -1.4 & 1.4 \\
\hline Portugal & 0.6 & 4.8 & 1.9 & -2.3 & 2.3 \\
\hline Greece & 0.2 & 7.4 & 2 & -5.2 & 5.2 \\
\hline
\end{tabular}

Source: own calculations based on (The Eurostat database, n.d.). 
between real GDP growth rates and real interest rates, which enabled indicating the average values of the primary balance ensuring the stabilization of public debt ratios in real terms.

On the basis of Table 7 it can be concluded that, in order to stabilize the public debt ratio (in relation to GDP), most of the less developed countries (mainly the new EU members) not only did not have to stabilize the total budget, but even the primary balance as its constituent element. As many as nine out of the twelve analysed countries in the group (apart from Hungary, Cyprus and Croatia) could afford a primary deficit above $0.5 \%$ of GDP. Only the last two had to obtain a primary surplus so that their public debt ratio did not increase.

Most of the EU-15 were in a much worse situation in that respect. Among them, a primary surplus had to be generated by five countries (Greece, Portugal, Italy, France and Denmark) in order to stabilize their debt ratios. Out of those countries, only the first two are not currently in the group of the most developed EU countries.

However, among the EU-15 only five countries - Luxembourg, Ireland, Sweden, Austria and the United Kingdom - could afford a primary deficit above $0.5 \%$ of GDP.

The strong association between primary balance values ensuring the stabilization of public debt ratios and debt ratios themselves in the study period is indicated by the high $(0.81)$ correlation coefficient. Yet $i$ is worth emphasizing that an equally high correlation coefficient $(-0.81)$ occurred between primary balance values, ensuring the stabilization of public debt ratios and average economic growth rates in the period 2001-2018.

It should be noted that the difference regarding the debt ratio stabilization conditions is related to the factors already partly discussed in the previous paragraphs. First of all, the new EU member states in the vast majority of cases showed a higher economic growth rate. Considering the construction of the debt ratio, this meant that it was much easier for them to stabilize, or at least on a smaller scale, to increase the debt ratio. Secondly, usually higher inflation in this group of countries meant that real interest rates were typically lower there than in the EU-15, despite the fact that nominal interest rates on bonds were often slightly lower, for a change, in the latter (due to the higher rating associated with their greater macroeconomic credibility).

\section{Conclusion}

The analysis allows to draw two very important conclusions:

1) As a rule, except for extreme cases, richer countries are more indebted than poorer ones. However, this does not confirm the validity of the thesis that the Keynesian effects of expansionary fiscal policy prevailed in Europe in 2000-2018. Firstly, correlation coefficients were not high, especially at the end of the study period. Secondly, different conclusions could be drawn if the relationship between public debt and real GDP growth rate was examined (instead of GDP per capita). 
2) The diversity of the public debt ratios in the EU countries needs not be explained only by the Keynesian and non-Keynesian effects. Alternatively, this can also be explained by other determinants. The most important of them include:

(a) real convergence process,

(b) different inflation rates and resulting initial debt levels at the end of the previous century,

(c) different conditions for stabilizing the public debt ratio taking into account the primary balance.

In this context, it is worth noting that the complex chain of mutual economic dependencies in changing economic conditions means that individual variables can often be treated as both exogenous and endogenous on the macro-scale. In this article the analysis reversed the situation compared to mainstream research. That means that the public debt ratio was adopted as an endogenous variable to examine how other variables impact on its values (e.g. real GDP growth rate and inflation rate).

\section{References}

Afonso, A., and Sousa, R. M. (2011). The macroeconomic effects of fiscal policy. Applied Economics, 44(34).

Bukowski, S. I. (2011). Kryzys fiskalny i przyszłość Unii Ekonomicznej i Monetarnej. In S. I. Bukowski \& J. Misala (Eds.), Wzrost gospodarczy i finanse międzynarodowe. Warszawa: CeDeWu.pl, Wydawnictwo Fachowe.

Burda, M., Wyplosz, Ch. (2000). Makroekonomia. Podręcznik europejski. Warszawa: Polskie Wydawnictwo Ekonomiczne.

Cassimon, D., Moreno-Dodson, B., Wodon, Q. (2008). Debt sustainability for low-income countries: A review of standard and alternative concepts, Munich Personal RePEc Archive, January.

Castro, F., Cos, P. H. (2008). The economic effects of fiscal policy: The case of Spain. Journal of Macroeconomics, 30(3).

Christiano, L., Eichenbaum, M., and Rebelo, S. (2009). When is the government spending multiplier large? NBER Working Paper Series, (15394).

Eggertsson, G. B. (2011). What fiscal policy is effective at zero interest rates? NBER Macroeconomics Annual 2010, 25.

Fatás, A. and Mihov, I. (2001). The effects of fiscal policy on consumption and employment: Theory and evidence. CEPR Discussion Paper, (2760).

Favero, C. (2002). How do European monetary and fiscal authorities behave? CEPR Discussion Paper, (3426).

Gale, W. G., Orszag, P. R. (2003). Economic effects of sustained budget deficits. National Tax Journal, $56(3)$.

Giordano, R., Momigliano, S., Neri, S., and Perotti, R. (2007). The effects of fiscal policy in Italy: Evidence from a VAR model. European Journal of Political Economy, (23).

Giudice, G., Turrini, A., and Veld, J. (2003). Can fiscal consolidations be expansionary in the EU? Ex-post evidence and ex-ante analysis. Economic Papers, (175), European Commission, Directorate-General for Economic and Financial Affair, Brussels.

Grabia, T. (2015). Finanse publiczne najważniejszych gospodarczo krajów europejskich. Wiadomości Statystyczne, (4). 
Kwon, G., McFarlane, L., and Robinson, W. (2006). Public debt, economic growth and inflation: A cross-country study and its application to Jamaica. IMF Working Papers, (06/121).

Lopes da Veiga, J., Ferreira-Lopes, A., and Sequeira, T. (2014). Public debt, money supply and inflation in African economies. MPRA Paper, (57377).

Mishkin, F. S. and Savastano, M. A. (2000). Monetary Policy Strategies for Latin America. NBER Working Paper, (7617).

Mountford, A., and Uhlig, H. (2005). What are the effects of fiscal policy shocks? Humboldt-Universität zu Berlin Working Paper SFB, (649).

Nguyen, V. B. (2015). The relationship between public debt and inflation in developing countries: Empirical evidence based on difference panel GMM. Asian Journal of Empirical Research, 5(9).

Perotti, R. (2003). Estimating the effects of fiscal policy in OECD countries. ECB Working Paper, 168.

Ramey, V., and Shapiro, M. (1998). Costly capital reallocation and the effects of government spending. Carnegie Rochester Conference on Public Policy, (48).

Reinhart, C. M., and Rogoff, K. S. (2010). Growth in a time of debt. American Economic Review, (100).

Reynolds, A. (2001). The fiscal-monetary policy mix. Cato Journal, 21(2).

Rocznik Statystyczny RP. (1997). Warszawa: GUS.

Romero, J. P. B., and Marin K. L. (2017). Inflation and Public Debt, Monetaria, V(1).

Rosati, D. (2013). Konsolidacja fiskalna a kryzys zadłużenia w strefie euro. In L. Oręziak, D. K. Rosati, Kryzys finansów publicznych. Przyczyny. Mechanizm. Drogi wyjścia. Warszawa: Oficyna Wydawnicza Uczelnia Łazarskiego.

Rzońca, A. (2007). Czy Keynes się pomylit? Skutki redukcji deficytu w Europie Środkowej. Warszawa: Wydawnictwo Naukowe SCHOLAR.

The Eurostat database (n.d.), Retrieved: August 1, 2019 from http://epp.eurostat.ec.europa.eu 